\title{
Effect of Temperature and Asphalt Binder Type on the Properties of Foamed Asphalt Mix
}

\author{
Martin Bitolog ${ }^{1}$, Mouhamed Bayane Bouraima ${ }^{1}$, Xiao-hua Zhang ${ }^{2}$, Christian Magloire Ndjegwes ${ }^{1}$ and Yanjun Qiu ${ }^{1}$ \\ ${ }^{1}$ School of Civil Engineering, Southwest Jiaotong Univ., Highway Engineering Key Laboratory of Sichuan Province, Chengdu China. \\ ${ }^{2}$ Sichuan Provincial Transport Department Highway Planning, Survey, Design and Research Institute, Chengdu China.
}

\begin{abstract}
In this study, an effect of temperature on both indirect tensile strength (ITS) test and Marshall Stability Test of foam asphalt mixture using Shell \#70 A asphalt is firstly investigated. A detailed investigation of the mechanical properties of foam asphalt mixture was then carried out using two different asphalt binders. The experimental work compares the mechanical properties of foam asphalt mixes including water stability test, indirect tensile strength (ITS) test, and freeze-thaw splitting test. The test results indicate that the foam asphalt mixture is temperature dependent and also temperature sensitive material. The foaming properties of asphalt have an important effect on the properties of the foam asphalt mixture for the strength and water stability of the foam asphalt mixture.
\end{abstract}

\section{Introduction}

With the rapid development of transport infrastructure in China [1], the use of foamed bitumen as a stabilizing agent in pavement since 1956 [2] is improving steadfastly and internationally. Foamed technology has been used by numerous road and highway stabilization and recycling projects [3-6] after its production process is modified by injecting steam to cold water into hot bitumen in 1976 and also introducing new machineries in the market in mid-1990 [7].

The use of foam bitumen stabilization is imperative because of its high field performance properties and its environmentally friendly benefits [8-11]. Many factors such as bitumen type, grade, and additives; in particular, antifoaming agents often are added to bitumen produced by solvent precipitation processes affected its foaming characteristics.

Asphalt can be foamed at high temperature by adding approximately $2 \%$ amount of water to hot bitumen resulting in the formation of liquid asphalt binders, which is called foam asphalt [12]. Foamed bitumen advantages have grown in recent years and consist of (a) improving mix strength and durability, (b) increasing spectrum of aggregates usable, (c) reducing binder content, (d) improving workability, (e) propensity of using labor-intensive methods, (f) energy savings during the mix processing and others [13-16]. Foam asphalt technology has thus been widely used in asphalt pavement structure during the last decade all over the world [17-20]. China has mainly used it to use to recycle asphalt pavement [21]. The effects of asphalt binder properties on foamed asphalt mix properties were studied and reported by in references [22] and [23] respectively. They have concluded through their investigation that asphalt binders with higher expansion ratio and longer half-life tend to produce better quality foamed asphalt mixes

Use of new aggregate in foam asphalt mixture is also a good choice for new asphalt pavement structure. However, there is a difference between foam asphalt mixtures with foam asphalt recycled mixture in terms of the strong performance, it is imperative to research the strength characteristic in the laboratory. Mechanical performance of cold foamed bitumen mixes was investigated through laboratory [24] using bitumen source, foaming additive, fiber reinforcement and cement effect. The mechanical properties included dynamic modulus and indirect direct tensile strength of dry and conditioned specimens. The results show that bitumen with low foamability provided better mechanical performance than that with the better foamability.

The objectives of this study were to first investigate the effect of temperature on both indirect tensile strength (ITS) test and Marshall Test of foam asphalt mixture using Shell \#70 A asphalt and secondly to see the effect of two different asphalt binder type on the mechanical properties of foam asphalt mixture.

\section{Materials and test program}

Zhonghai \# 90 A grade asphalt and Shell \#70 A bitumen currently used in China were investigated. For each source, penetration, viscosity, and softening point were measured. They used to produce foam asphalt at $150^{\circ} \mathrm{C}$. Water content is $4 \%$ of asphalt mass when producing foam asphalt. Physical properties of base asphalt for the two sources and their respective foaming characteristics are shown in Table 1. The mixture design gradation is 
given in Table 2. The optimal water content of foam asphalt mixture is determined by Marshall 75 times compaction test. The optimal foam asphalt content is $3.5 \%$.

\section{Test program}

\subsection{Water Stability}

The residual Marshall stability is used as the index to evaluate the water stability according to the Chinese Technical Specification for Construction of Highway Asphalt Pavement. Standard Marshall Test and immersion Marshall Test were conducted according to Chinese specification T0709-2011, and then the residual stability can be determined from the Marshall stability and the immersion Marshall Stability according to formula (1)

$$
S=\frac{s_{1}}{s_{0}} \times 100
$$

where $\mathrm{S}$ is the residual stability, $\% ; S_{1}$ is the immersion Marshall stability, $\mathrm{kN}$; and $S_{0}$ is the Marshall stability, $\mathrm{kN}$.

\subsection{Indirect tensile strength test}

For the indirect tensile test, Marshall specimens were subjected to compressive loads in equipment fabricated for this purpose. The tests were conducted at $25^{\circ} \mathrm{C}, 50$ $\mathrm{mm} / \mathrm{min}$ loading rate. The test procedure adopted was as per Chinese specifications JTJ T0716-2011. The split strength can be obtained according to formula (2).

$R_{T}=\frac{0.006287 P_{T}}{h}$

in which, $\mathrm{R}_{\mathrm{T}}$ is a split strength $(\mathrm{MPa}), \mathrm{h}$ : displacement $(\mathrm{mm})$, and $\mathrm{P}_{\mathrm{T}}$ is the load when specimen destroyed $(\mathrm{N})$.

\subsection{Comparison of freeze-thaw splitting}

The tensile strength ratio is defined as the tensile strength of specimen after freeze-thaw conditioning compared to the tensile strength of specimen at ambient temperature. During the freeze-thaw conditioning, the specimen is immersed in water under vacuum state for $15 \mathrm{~min}$, then froze at $-18^{\circ} \mathrm{C}$ in the refrigerator for $16 \mathrm{~h}$, and then immersed in $60^{\circ} \mathrm{C}$ water for $24 \mathrm{~h}$. The splitting strength tests were carried out according to the Standard Test Methods of Bitumen and Bituminous Mixtures for Highway Engineering, and the maximum strength values were recorded. The tensile strength ratio (TSR) can be calculated based on Eq. 2 .

$T S R=\frac{R_{T 2}}{R_{T 1}}$

Where TSR: freeze-thaw strength ratio, $\%, \mathrm{R}_{\mathrm{T} 1}$ : strength without freeze and thaw, $\mathrm{MPa}, \mathrm{R}_{\mathrm{T} 2}$ : Strength after freeze and thaw, $\mathrm{MPa}$.

\section{Test results and discussion}

\subsection{Comparison of test indexes under different temperature}

The effect of temperature on both indirect tensile strength (ITS) test and Marshall Test of foam asphalt mixture using Shell \#70 A asphalt is investigated. The test results of dry and wet indirect tensile strength test at $25^{\circ} \mathrm{C}$ are shown in Table 3. Table 4 shows the results of dry wet indirect tensile strength test under different temperatures. The Marshall test results at $40^{\circ} \mathrm{C}$ and $60^{\circ} \mathrm{C}$ are shown in Table 5.

Table 1. Physical property of the two asphalt binders

\begin{tabular}{cccc}
\hline Test items & Unit & Shell \#70 A & Zhonghai \# 90 A \\
\hline Penetration $\left(25^{\circ} \mathrm{C}\right)$ & $0.1 \mathrm{~mm}$ & 65 & 84 \\
Ductility $\left(10^{\circ} \mathrm{C}\right)$ & $\mathrm{cm}$ & 34 & 135 \\
Softening point & ${ }^{\circ} \mathrm{C}$ & 47.5 & 48 \\
Dynamic viscosity $\left(135^{\circ} \mathrm{C}\right)$ & $\mathrm{Pa} . \mathrm{s}$ & $1 . .71$ & 1.73 \\
Density $\left(15^{\circ} \mathrm{C}\right)$ & $\mathrm{g} / \mathrm{cm}^{3}$ & 1.02 & 1.03 \\
Expansion ratio & & 6 & 14 \\
Half-life & $\mathrm{s}$ & 5 & 8 \\
\hline
\end{tabular}

Table 2. Foam asphalt mixture gradation

\begin{tabular}{|c|c|c|c|c|c|c|c|c|c|c|c|}
\hline \multicolumn{12}{|c|}{ Passing percentage $(\%)$ of each mesh sieve $(\mathrm{mm})$} \\
\hline 26.5 & 19 & 16 & 13.2 & 9.5 & 4.75 & 2.36 & 1.18 & 0.6 & 0.3 & 0.15 & 0.075 \\
\hline 100 & 96.4 & 92.6 & 82.5 & 76.6 & 53.5 & 37.7 & 28.8 & 22 & 15.8 & 13.4 & 11 \\
\hline
\end{tabular}

Table 3. $25^{\circ} \mathrm{C}$ dry and wet indirect tensile strength test

\begin{tabular}{|c|c|c|}
\hline Test item & $25^{\circ} \mathrm{C}$ dry ITS & $24 \mathrm{~h} 25^{\circ} \mathrm{C}$ soaking wet ITS \\
\hline Average value & 0.417 & 0.353 \\
\hline Dry ITS/wet ITS & & \\
\hline
\end{tabular}

Table 4. $15^{\circ} \mathrm{C}$ and $25^{\circ} \mathrm{C}$ dry wet $t$ indirect tensile strength test

\begin{tabular}{ccccc}
\hline Test item & $15^{\circ} \mathrm{C}$ dry ITS & $15^{\circ} \mathrm{C}$ soaking wet ITS & $25^{\circ} \mathrm{C}$ dry ITS & $25^{\circ} \mathrm{C}$ soaking wet ITS \\
\hline
\end{tabular}




\begin{tabular}{cccccc}
\hline Average value & 0.4853 & & 0.4669 & 0.417 & 0.353 \\
Dry ITS/wet ITS & & $96.8 \%$ & & & $84.7 \%$ \\
\hline
\end{tabular}

Table 5. $60^{\circ} \mathrm{C}$ and $40^{\circ} \mathrm{C}$ Marshall test

\begin{tabular}{ccc}
\hline Test item & $60^{\circ} \mathrm{C}$ standard Marshall stability (35min) & $40^{\circ} \mathrm{C}$ immersion Marshall stability (35min) \\
\hline Average value & 5.96 & 9.1 \\
\hline
\end{tabular}

Note: ITS stands for indirect tensile strength.

Table 6. Water stability test results

\begin{tabular}{llll}
\hline Asphalt binder type & $\begin{array}{c}40^{\circ} \mathrm{C} \text { standard Marshall } \\
\text { stability }(\mathrm{kN}, 35 \mathrm{~min})\end{array}$ & $\begin{array}{c}40^{\circ} \mathrm{C} \text { Immersion stability } \\
(\mathrm{kN}, 48 \mathrm{~h})\end{array}$ & Residual stability $(\%)$ \\
\hline Shell \#70 A & 9.1 & 8.89 & 97.7 \\
\hline Zhonghai \# 90 A & 9.23 & 9.21 & 99.8 \\
\hline
\end{tabular}

Table 7. $25^{\circ} \mathrm{C}$ Indirect tensile test results

\begin{tabular}{c|c|c|c|c|c}
\hline \multicolumn{3}{c|}{ Shell \#70 A asphalt } & \multicolumn{3}{c}{ Zhonghai \# 90 A asphalt } \\
\hline Dry ITS (MPa) & Wet ITS (MPa) & Dry/Wet ratio & Dry ITS (MPa) & Wet ITS (MPa) & Dry/Wet ratio \\
\hline 0.417 & 0.353 & $84.6 \%$ & 0.485 & 0.415 & $85.5 \%$ \\
\hline
\end{tabular}

Table 8. Comparison of freeze-thaw splitting test results

\begin{tabular}{c|c|c|c|c}
\hline \multirow{2}{*}{ Test item } & \multicolumn{2}{|c|}{ Shell \#70 A asphalt } & \multicolumn{2}{c}{ Zhonghai \# 90 A asphalt } \\
\cline { 2 - 5 } & Before freeze-thaw & $\begin{array}{c}\text { After freezing and } \\
\text { thawing }\end{array}$ & $\begin{array}{c}\text { Before freeze-thaw } \\
\text { After freezing and } \\
\text { thawing }\end{array}$ \\
\cline { 2 - 5 } & 0.3924 & 0.303 & 0.3819 & 0.3648 \\
\hline Wet and dry splitting ratio & \multicolumn{2}{|c|}{$77.2 \%$} & & $95.5 \%$ \\
\hline
\end{tabular}

Through Tables 3 to 5 , it can be seen that the properties of the foam asphalt mixture are temperature dependent and are also temperature sensitive materials. The dry-wet ITS ratio of foam asphalt mixture at $15^{\circ} \mathrm{C}$ increased obviously than that of $25^{\circ} \mathrm{C}$, and the dry ITS increased $40.4 \%$ while that of wet ITS increased by $60.6 \%$

\subsection{Mechanical properties of foam asphalt mixture.}

The compared performance properties of foam asphalt mixture from two kinds of asphalt binder including water stability, indirect tensile strength, and freeze-thaw splitting was carried. The results of water stability tests were shown in Table 6.

It can be seen from Table 6 that the water stability of these two foam asphalt mixtures meets the specification requirement. And the residual stability of Zhonghai \# 90 A asphalt mixture is greater than that of Shell \#70 A, which means that the water stability of Zhonghai \# 90 A asphalt mixture is better than that of Shell \#70 A asphalt mixture. There is no much difference from Shell \#70 A asphalt and Zhonghai \# 90 A asphalt, after 48 hours of immersion Marshall Attenuation. The above test data demonstrate that the Marshall stability is not sensitive to the performance of the foamed asphalt and that the Marshall stability can meet the specified requirements when the foaming performance is poor. Table 7 presents the results of the indirect tensile test.

From the Table 7, it can be seen that the dry splitting strength of Zhonghai \# 90 A asphalt is $16.3 \%$ higher than shell asphalt while its wet splitting strength is $17.5 \%$ higher. Whether it is dry or wet splitting, the Zhonghai \# 90 A asphalt has a better strength ability compare to Shell \#70 A asphalt. The results of the freeze-thaw splitting test for the two sources of asphalt are shown in Table 8.

It can be seen that after a freeze-thaw cycle, the wet splitting strength of both Shell \#70 A and Zhonghai \# 90 A foam asphalt mixtures decreased in varying degrees. After the freeze-thaw cycle, the water stability of Zhonghai \# 90 A foam asphalt mixture is better than that of Shell \#70 A foam asphalt mixture, and after a freezing-thawing cycle the water stability of Shell \#70 A foamed asphalt mixture was significantly decreased

\section{Conclusion}

The aim of this study is to first investigate the effect of temperature on both indirect tensile strength (ITS) test and Marshall Test of foam asphalt mixture using Shell \#70 A asphalt and secondly to see the effect of two different asphalt binder type on the mechanical properties of foam asphalt mixture. The main conclusions drawn from the current research work are presented as follows:

- Foam asphalt mixture is temperature dependent and 
are also temperature sensitive materials

- The water stability of Zhonghai \# 90 A asphalt mixture is better than that of Shell \#70 A asphalt mixture.

- Foam asphalt mixture with Zhonghai \# 90 A asphalt has a better indirect tensile strength compared to that of the Shell \#70 A asphalt.

- The water stability of Zhonghai \# 90 A foam asphalt mixture is better than that of Shell \#70 A foam asphalt mixture after the freeze-thaw cycle.

\section{References}

1. Bayane, B. M., Yanjun, Q. (2017). Transport infrastructure development in China. Journal of Sustainable Development of Transport and Logisti2cs, 2 (1), 29-39. doi:10.14254/JSDTL.2017.2-1.3.

2. Csanyi LH, 1957. Foamed asphalt in bituminous pavements. Design procedures for soil modification or stabilization. IN, USA: Division of Engineering and Asset Management, Office of Geotechnical Services; 2013, February.

3. Wirtgen Cold Recycling Technology, 2012. The Wirtgen Cold Recycling Manual, Wirtgen $\mathrm{GmbH}$, Windhagen, Germany.

4. Geoff J, 2013. Design and performance of foamed bitumen stabilized pavements: progress report 1 . Australia: Austroad Ltd.

5. Abel, F., 1978. Foamed Asphalt Base Stabilization. Proc.,6th Annual Asphalt Paving Seminar, Colorado State Univ,Dec.7-8,1978.

6. Acott, S.M., 1979. Sand Stabilisation Using Foamed Bitumen. In: 3rd Conference on Asphalt Pavements for Southern Africa, 3rd, 1979, Durban, pp.155-172.

7. Mohammad LN, Abu-Farsakh MY, Wu Z, Abadie C, 2003. Louisiana, experience with foamed recycled asphalt pavement base materials. USA: Transportation Research Board, TRR 1832; 2003: pp. 17-24.

8. Saleh, M. F. New Zealand Experience with Foam Bitumen Stabilization. In Transportation Research Record: Journal of the Transportation Research Board, No. 1868, Transportation Research Board of the National Academies, Washington, D.C., 2004, pp. 40-49.

9. Kaveh Ostad-Ali-Askari, Mohammad Shayannejad. The Study of Mixture Design for Foam Bitumen and the Polymeric and Oil Materials Function in Loose Soils Consolidation. Journal of Civil Engineering Research 2015, 5(2): 39-44 DOI: 10.5923/j.jce.20150502.04

10. Saleh, M. F. Effect of Aggregate Gradation, Mineral Fillers, Bitumen Grade, and Source on Mechanical Properties of Foamed Bitumen-Stabilized Mixes. Transportation Research Record: Journal of the Transportation Research Board. Issue Number: 1952. 2006.

11. Saleh, M. F. Cost evaluation of foam bitumen and other stabilization alternatives. International Journal of Pavement Engineering, Vol. 00, No. 0, 2006, 1-5. DOI: $10.1080 / 10298430601149585$
12. Csanyi, L. H, 1963. Foamed Asphalt for Economic Road Construction. Civil Engineering, Vol. 32, No. 6, pp. 62-69.

13. Namutebi, M., Birgisson, B., \& Bagampadde, U, 2011. Foaming effects on binder chemistry and aggregate coatability using foamed bitumen. International Journal of Road Materials and Pavement Design, 12(4), 821-847.

14. S. W. Du et al., "The Mechanical Properties of Foam Asphalt Mixture", Applied Mechanics and Materials, Vols. 71-78, pp. 1150-1153, 2011.

15. Gaudefroy, V., Olard, F., Cazacliu, B., Roche, C.L., Beduneau, E., \& Antoine, J.P, 2007. A laboratory investigation on the mechanical performances of foamed bitumen mixes using half-warm aggregates. TRB 2007 Annual Meeting CD-ROM.

16. Muthen, K.M, 1998. Foamed asphalt mixes-mix design procedure (Contract Report CR-98/077). Pretoria, South Africa: SABITA Ltd \& CSIR Transportek.

17. Ruenkrairergsa, T., Phromsorn, C., Silarom, P. and Ketnoot, W., 2004. Engineering Properties of Foamed Bitumen Mixtures in Thailand. Proceedings of the 8th Conference on Asphalt Pavement for Southern Africa (CAPSA '04), ISBN No. 1-920-01718-6, 12-16 September 2004, Sun City, South Africa.

18. Chiu, C.T. and Huang, M.Y., 2002. A Study on Properties of Foamed Asphalt Treated Mixes. Chung Hua University, Department of Civil Engineering, No.30 Tung Shiang, Hsin Chu,300, Taiwan

19. Sakr, H.A. \& Manke, P.G., 1985. Innovations in Oklahoma Foamix Design Procedures. In: Asphalt materials, mixes, construction and quality. Washington, DC: Transportation Research Board. (Transportation Research Record; 1034), pp 26-34.

20. He, Z. and Lu, W., 2004. Research on the Properties of Road Building Materials Treated with Foamed Bitumen in China. Proceedings of the 8th Conference on Asphalt Pavement for Southern Africa (CAPSA '04), ISBN No. 1-92001718-6, 12-16 September 2004, Sun City, South Africa..

21. LI Xiu-jun, SHI Fang-Zhi, ZHANG Yong-ping. Journal of Tongji University (Natural Science); 2009 (01):47-50.

22. Jenkins KJ. Mix design considerations for cold and half-cold bituminous mixes with emphasis on foamed bitumen. Ph.D. Thesis, University of Stellenbosch, South Africa; 2000.

23. Pengcheng Fu, David Jones, John T. Harvey, 2011. The effects of asphalt binder and granular characteristics on foamed asphalt mix strength. Construction and Building Materials, (25): 1093-1101.

24. Gilberto Martinez-Arguelles, Filippo Giustozzi, Maurizio Crispino, Gerardo W. Flintsch, 2015. Laboratory investigation on mechanical performance of cold foamed bitumen mixes: Bitumen source, foaming additive, fiber-reinforcement and cement effect. Construction and Building Materials. Volume (93): 241-248. 